\title{
Analysis of Climate Variability and Relation to Vegetation in Garamba National Park from 1990-2020
}

\author{
Lutumba Suika Achille, Kebin Zhang*, Christian Jonathan Kouassi Anoma \\ College of Soil and Water Conservation, and Desertification Combating, Beijing Forestry University, Beijing, China \\ Email: achillelutumba@gmail.com, achille@bjfu.edu.cn, *ctccd@bjfu.edu.cn,jkouassi83@yahoo.com
}

How to cite this paper: Achille, L.S., Zhang, K.B. and Anoma, C.J.K. (2021) Analysis of Climate Variability and Relation to Vegetation in Garamba National Park from 1990-2020. Open Journal of Ecology, 11, 700-723.

https://doi.org/10.4236/oje.2021.1110044

Received: September 5, 2021

Accepted: October 26, 2021

Published: October 29, 2021

Copyright () 2021 by author(s) and Scientific Research Publishing Inc. This work is licensed under the Creative Commons Attribution International License (CC BY 4.0).

http://creativecommons.org/licenses/by/4.0/

\section{(c) (i) Open Access}

\begin{abstract}
Climatic factors impact vegetation. Our study was to examine and analyze the climate variability and relationship to vegetation in Garamba National Park of the Democratic Republic of the Congo over the past 30 years (1990 to 2020), then to relate the climatic variables. Mann Kendall's non parametric test, ANOVA, and p-value tests are used to analyze existing trends and relationships between vegetation cover, climatic factors, land surface temperature (LST) and normalized difference in temperature Vegetation index (NDVI), Enhanced vegetation index (EVI) in Garamba national park which is of particular importance for the network of protected areas of the Democratic republic of Congo because its position at the northern limit of the savanna-forest mosaics gives it a unique biodiversity. The southern part of the park is dominated by grassy shrub savannas. The results showed that: 1) In Garamba, the monthly correlation coefficient of Kendall and Pearsan between temperature and precipitation are negative respectively 0.763 and -0.876 (p-value $<0.00001) .2$ ) Annually during the three decades in Garamba, the correlation between precipitation and NDVI is significant 0.416 (Kendall) and 0.496 (Pearsan); the same between precipitation and EVI 0.291 (Kendall) and 0.496 (Pearsan) while LST and precipitation are negatively correlated (p-value $<0.00001)$.
\end{abstract}

\section{Keywords}

Remote Sensing, Correlation Coefficient, Vegetation, Land Surface Temperature, Enhanced Vegetation Index, Normalized Difference Vegetation Index

\section{Introduction}

The Democratic Republic of Congo presents Congolese forests as a public herit- 
age, essential for the survival of millions of the world's poorest people, and for the global environment. It examines the mismanagement liabilities of these forests prior to independence [1] and the tensions related to post-conflict recovery. It highlights the risk that forests will continue to be exploited for personal gain, and that the inhabitants of these forests, the country and the global environment are in these respect victims of peace. Against this backdrop, this thesis targets problems that could cause irreversible damage to society and the environment, or jeopardize future profits. It also illustrates the risk of inaction [2].

The forests of the DRC cover approximately 145 million hectares ( 85 of which are densely forested) out of a total area of 235 million hectares, or $62 \%$ of the national territory. It is the second largest tropical forest in the world after the Amazon, accounting for $2 / 3$ of the total forest mass of the Congo Basin, which is in the tropical zone. According to the summary forest map of [3], currently DIAF, the DRC has $1,280,042.46 \mathrm{~km}^{2}$ of forest formations. These cover about $54.59 \%$ of the total area of the national territory estimated at $2,345,000 \mathrm{~km}^{2}$. Dense rainforests represent about $60 \%$ of all forests [4]. [5] estimates that the forest cover has decreased from the former and currently represents a forest area of 154,135,000 ha. This evidence is also corroborated by [6]. But, considering the work undertaken by [2], the forest cover would be 145 million hectares.

Therefore, a general picture of the current state of vegetation cover in Garamba National Park by remote sensing using indices recognized under the names as Normalized difference vegetation index NDVI and Enhanced vegetation index EVI is an effective way to analyze the vegetation trend over the past 10 to 30 years. This vegetation index bears a numeric value to which can relate to land use and land cover (transformation of the land surface relative to the profit that man draws from this soil for a specified period) or the occupation of the land which can like India, the effectiveness of remote sensing in the fight against land degradation and as a tool to aid the decision-making process by political leaders has been demonstrated time and time again. Thus, the decision-making process must include scientific results and results as well as social needs for holistic resource management and avoiding conflicts due primarily to unfair management of society and nature [7]. Despite the accepted statutes suggesting that academic work is theoretical and far from political reality, it remains very important to take into account research findings that identify the needs of the population under particular climatic conditions to meet the crucial challenge of sustainable development in Africa and in particular in the Democratic Republic of Congo respond to a particular vegetation type.

The development of forestry should focus on the generalization of participatory approaches in all forestry activities, in a systematic effort to adequately meet both rural and industrial needs, both local and national [8]. The DRC, one of the most forested countries in the world, is not far behind, it has joined this effort to test this tool for development and fight against poverty and food insecurity in the world rural. With the support of its multinational and bilateral partners, she has carried out various experiments on several sites within the framework of 
projects executed by FAO. Many studies have been conducted by different forestry research institutions [9].

Some previous studies have proved that the variation of the temperature follows the trend of NDVI [10] and the other found that precipitation is the limiting factor of NDVI dynamic. Therefore, several methods have been proposed to measure and analyze the relationship between the plant biomass by using remote sensing [11]. This correlation study is remote sensing [11]. Forestry is thus almost summoned to contribute significantly to the solution of the problems of environmental degradation and rural poverty. Therefore, it becomes imperative to involve fully and directly populations that are both actors and beneficiaries of activities forestry [12].

To address the challenge of the vegetation variability in this work, the following several statements were formed:

1) Are there any changes in vegetation and in DRC and Garamba national park?

To address the challenge of the vegetation variability in this work, the following several statements were formed:

2) Is there any relationship between vegetation and land surface temperature in Garamba National Park?

There are significant changes in vegetation cover in Garamba National Park in past 30 years, and these dynamics related strongly with climatic factors such as temperature.

Estimates of the total area of cover Democratic republic of Congo's foresters vary according to the various Sources. This seems to be due to the fact that there is no forest inventory yet Systematic. The change in estimates would be due, on the one hand, to the difference methods used, and on the other hand, at times of observations made. As an illustration, according to the DRC forest map issued by the Directorate Inventories and Forest Developments (DIAF) of the Ministry of the Environment, Nature Conservancy and Tourism (MECNT), the forest would occupy an area $1,280,042.46 \mathrm{sq} \mathrm{km}$, representing $56.59 \%$ the total area of the national territory, itself estimated at 2,345,000 sq $\mathrm{km}$. The document reporting the forests of the Congo Basin in 2008 estimates that the forest area of DRC to 155.5 million hectares on an area 2,329,374 sq km of the national territory, $67 \%$ of the DRC's national territory [13]. This estimate of the DRC's forest [14] area is broadly confirmed by the work of [15] as part of the Forest Atlas Global Forest Watch and MECNT. [5] estimates that forest cover has increased recorded a decrease compared to the first few statistics, and that it currently represents 154,135,000 hectares of forest area. This statistics is also corroborated by [6]. But, taking into account the work committed by [2], forest is said to be 145 million hectares.

In Democratic republic of Congo; the climates and the vegetation determine four distinct zones: Equatorial type zone in the central basin; two tropical type zones favorable to wooded savannah and a dense forest and a zone at altitude, less hot and less watered, to the east and the south east. 
Natural borders limit the Park on three sides and present considerable advantages from the point of view of its protection. To the south, it is bounded by the Dungu River, which, joining the Kibali, will form, further downstream, the Uele; to the west, the Aka River, a tributary of the Dungu, borders it over its greatest length, while to the west, the upper course of the Garamba river determines, in large part, its territory.

Unfortunately, a large breach is opening in this protective device in the North and North-East. The Sudanese border constitutes, in this part, the northern limit; it is formed there by the ridge dividing the waters of the Congo and the Nile.

By its nature, the regional morphology is uncomplicated. The whole of the Garamba National Park is made up of a wavy pen plain [16], with a low slope, oriented in the North-East-South-West direction. This leveling surface belongs to the flats of the Congo-Nile crest; resulting from a primitive pen plain, dating from the Tertiary era, it was subjected later, and in particular during the Pleistocene, to cycles of intense erosion corresponding to the digging of the valleys. Its altitude is $710 \mathrm{~m}$ at the bridge over the Dungu and Kibali rivers in Dungu, from where it rises some $150 \mathrm{~m}$, through a series of valleys, to end at a rocky threshold, a presumed consequence of the buckling that affected the entire center. Most likely this uprising was at the origin of the modification of the hydrographic basins. We can, in fact, suppose that the hydrographic network of the Uele once flowed into the Chad basin [17].

Garamba national park was also designated as a world heritage site by UNESCO in 1980, the park used to have the largest concentration of elephants numbering 20,000 in the early 60 s and 70 s by 2017 there were only 2000 elephants in the park. Garamba National Park is home to over 1000 species of trees. 5\% of this is endemic to this area. The park is fed by three rivers; river Garamba, river Dungu and river Aka, it's located near the border of Congo and South Sudan.

The park covers three different biomasses: gallery forest with forest clumps and swamps, aquatic and semi-aquatic environments, and savanna. The savanna has an amazing range of dense woodlands and nearly treeless grasslands. The center of the park is a long grass savanna that covers most of the park.

We analyze the impact of climatic variability on the vegetation of Garamba National Park over three decades.

This study allows us to explore climatic variations and drivers between climates. It also provides an opportunity to study the effects of climate variability on the environment and health. It fills gaps in research on Garamba National Park by combining climate and vegetation variation using NDVI, LST, EVI data to clarify the relationship between vegetation and climate change under tropical climate conditions.

\section{Materials and Methods}

\subsection{Study Area}

The site in which the experimental plots of this study will be installed is the Ga- 
ramba National Park (Figure 1) with an area of $4900 \mathrm{~km}^{2}$ is located in the Northeast of the Democratic Republic of Congo, and shares its northern border with South Sudan. The $4900 \mathrm{~km}^{2}$ Garamba National Park is located in the north-east of the Democratic Republic of Congo, and shares its northern border with South Sudan; $3^{\circ} 45^{\prime} \mathrm{N}-4^{\circ} 41^{\prime} \mathrm{N}, 28^{\circ} 48^{\prime} \mathrm{E}-30^{\circ} 00^{\prime} \mathrm{E}$, altitude: 710 - $1061 \mathrm{~m}$; framed by the $29^{\text {th }}$ and West meridians, while, from South to North, it stretches between parallels $3^{\circ} 8^{\prime}$ and $4^{\circ} 4^{\prime}$ North, over an area estimated at $4900 \mathrm{~km}^{2}$ by the gravimetric method.

It is surrounded by 3 hunting areas namely: (Figure 2)

1) The Hunting Estate of GangalanaBodio $\left(2652 \mathrm{~km}^{2}\right)$

2) The Azandé Hunting Estate $\left(2892 \mathrm{~km}^{2}\right)$

3) The Mondo Missa Hunting Estate $\left(1983 \mathrm{~km}^{2}\right)$

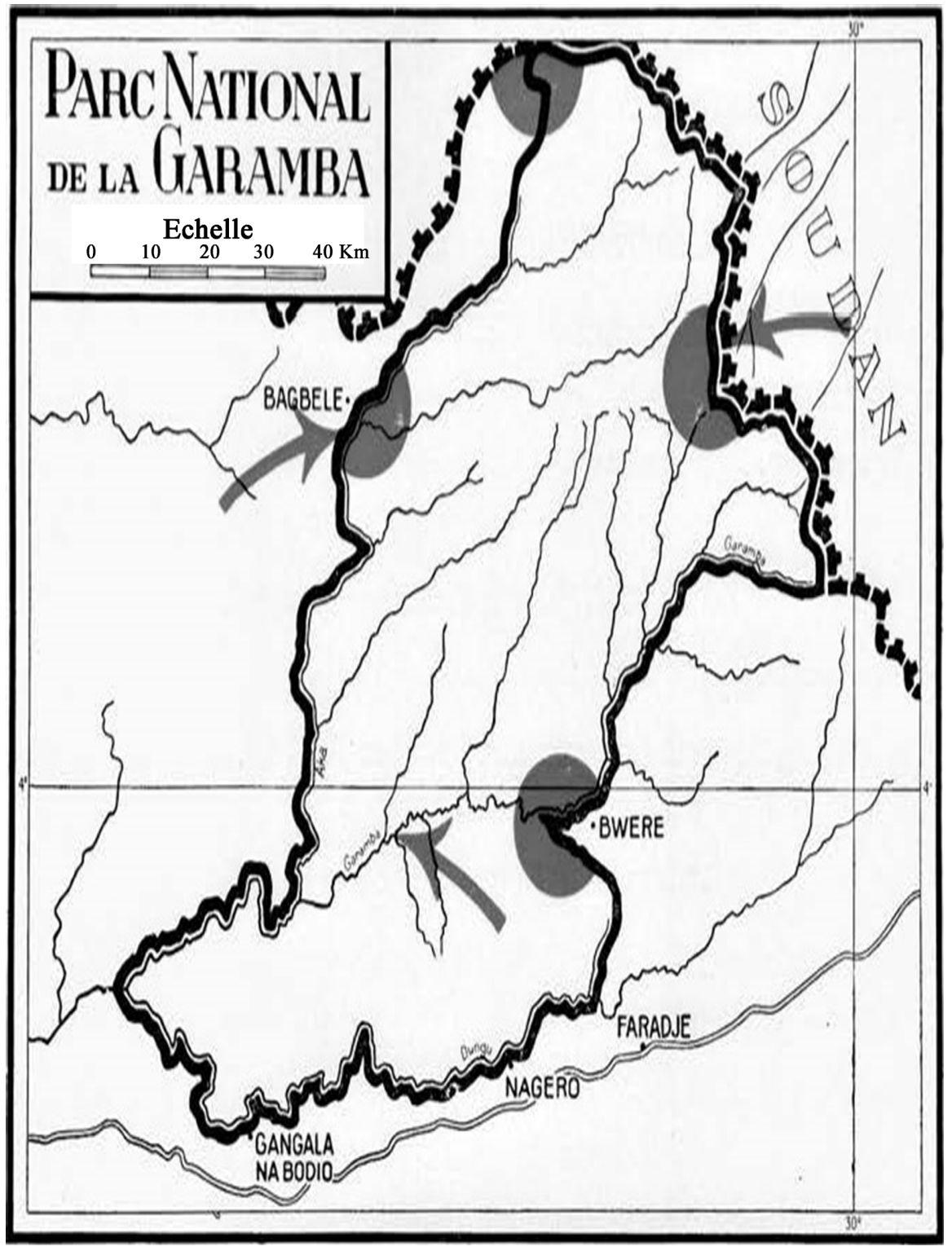

Figure 1. Garamba National Park. 

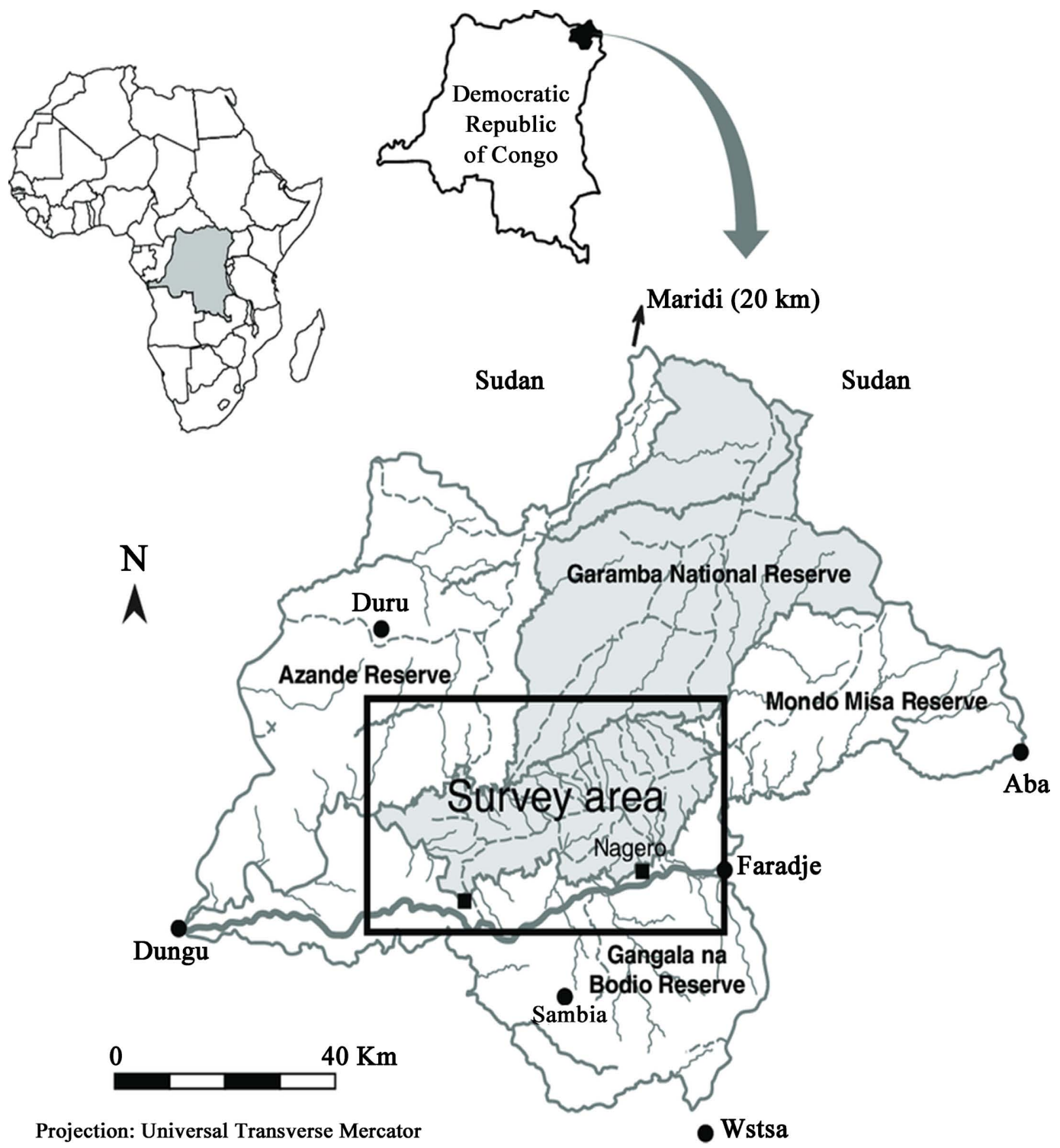

Projection: Universal Transverse Mercator

Figure 2. Garamba Park and hunting areas.

\subsection{Data Collection}

We used climate data available from official websites such as (http://earthexplorer.usgs.gov/; http://www.nasa.gov/;

https://ee-api.appspot.com/; climate engine to collect the data necessary for our research.

\subsection{Trend Analysis}

This correlation study is performed based on the regression analysis. Therefore, by the regression method which equation remains

$$
y=a x+b
$$

where $y$ is the variable to be explained (mostly the leaves or in certain case the dry matters) and $x$ representing the explained variable, $a$ and $b$ the coefficient of 
regression [18], the correlation can be searched and mathematically analyzed for concrete findings and quantification.

This regression method makes it possible to establish the correlation between the dependent variables and the independent variables of the series of our analysis. To determine this correlation, graphics and software were needed in the work.

Kendall's Tau is a correlation suitable for quantitative and ordinal variables. It indicates how strongly two variables are monotonously related: to which extent high values are on variable $x$ are associated with either high or low values on variable $y$ ?

We chose Mann Kendall's nonparametric method to assess the significance of these trends. How to detect them? Intra-annual changes and inter-annual changes consider a time series with $n$ records of observations each year for $m$ years. Let $\{i$, t\} $X=X$ be the observation value (for example, NDVI, EVI) at date $t$ of year $i$ with $i \in M=\{1,2, \cdots, m\}$ and $t \in T=\{1,2, \cdots, n\}$, where $n$ is the number of records in each year. The absolute difference $D=\left\{D_{i-1, i, t}, i \in M, t \in T\right\}$ is calculated between the two years of each date $t$ as (2).

$$
D_{i-1, i, t}=\left|X_{i-1, t}-X_{i, t}\right|
$$

Shifting from one type of land cover to another will lead to a dramatic change greatest value of $D$ at the time of the change. This jump should not occur on just one date but also the following days with a similar larger difference. It's because a change in land cover is likely to be of low frequency over a period and distinct recurring intra-annual variations.

Where $\kappa$ is a threshold and $p^{*}$ is the smallest number of records showing a deviation after the date of change. We have determined that $p^{*}$ is 3 , based on some trial and error experience.

The threshold $\kappa$ is calculated by multiplying a scale factor $(\beta)$ and the maximum of the absolute difference

$$
(\max D): \max K=\beta \cdot D
$$

where the value of the scale factor $\beta$ is determined during the learning process.

-1 and $i$ will be used to calculate $D$ and tested according to the two criteria of Equation (3) [19]. To know and quantify how obvious each trend appears, principle MK is often used. The MK method is suitable for nonparametric values of the data. In this case, the number of observations from 1990 to 2020 is equivalent to 30 years of observations in the Democratic Republic of the Congo in general and the Garamba National Park in particular.

The Mann-Kendall Test is used to determine whether a time series has a monotonic upward or downward trend. It does not require that the data be normally distributed or linear. It does require that there is no autocorrelation [20].

The null hypothesis for this test is that there is no trend, and the alternative hypothesis is that there is a trend in the two-sided test or that there is an upward trend (or downward trend) in the one-sided test. For the time series $x_{1}, \cdots, x_{n}$. 
The MK Test uses the following statistic:

$$
S=\sum_{i=1}^{n-1} \sum_{j=k+1}^{n} \operatorname{sign}\left(x_{j}-x_{i}\right)
$$

Note that if $S>0$ then later observations in the time series tend to be larger than those that appear earlier in the time series, while the reverse is true if $S<0$.

The variance of $S$ is given by

$$
\begin{gathered}
\operatorname{var}=\frac{1}{18}\left[n(n-1)(2 n+5)-\sum_{t} f_{t}\left(f_{t}-1\right)\left(2 f_{t}+5\right)\right] \\
\operatorname{Var}(S)=\frac{n(n-1)(2 n+5)}{18}
\end{gathered}
$$

When $S>0$, values measured later trend to be higher than earlier values showing growth.

When $S<0$, other values are smaller than earlier values showing a downward trend. Therefore, when the value of $S$ is smaller, no trend is observed. The MK Test uses the following statistic:

$$
r=\frac{S}{n(n-1) / 2}
$$

where $t$ varies over the set of tied ranks and $f_{t}$ is the number of times (i.e. frequency) that the rank $t$ appears.

The MK Test uses the following test statistic:

$$
\begin{aligned}
& z= \begin{cases}(S-1) / s e, & S>0 \\
0, & S=0 \\
(S+1) / s e, & S<0\end{cases} \\
& z=\frac{S-1}{\sqrt{\operatorname{Var}(S)}} \text { for } S \geq 0 \\
& Z=0 \text { for } S=0 \\
& z=\frac{S+1}{\sqrt{\operatorname{Var}(S)}} \text { for } S \leq 0
\end{aligned}
$$

where $s e=$ the square root of var. If the there is no monotonic trend (the null hypothesis), then for time series with more than 10 elements, $z \sim N(0,1)$, i.e. $z$ has a standard normal distribution.

$\tau$ has a range of minus one to plus one and is similar to quantifying the relationship between two factors. This case is used when there is a proof of a link between these components shown by a value of " $\tau$ " other than zero [21]. If and an obvious trend is found, the variation can be calculated using Sen's slope factor for the estimate.

$$
\beta=\operatorname{median}\left(\frac{Y j-Y j}{X j-X j}\right)
$$

The "p-value" of $\mathrm{M}-\mathrm{K}$ describes the distribution function and the dispersion of the values reported by [22] in 2002 . 
When the values are constant, $z$ evolves with a zero mean. When $z>0$ there is growth and when $z<0$ there is no growth and it decreases.

Where cumulatively describes the distribution function of a standard normal variant $(\mathrm{SNV})$.

$$
P=2[1-|Z|]
$$

\section{Results}

\subsection{Correlation between Monthly Temperature and Monthly Precipitation at Garamba}

Table 1 shows the average precipitation and maximum temperatures over a year in Garamba National Park. This table will serve as a guide for the completion of our work.

The regression of precipitation is linear as shown in Figure 3 because the variability of precipitation is incredible from March to November. August is considered being the peak of this variation with an average precision of $132 \mathrm{~mm}$.

Figure 4 shows the monthly temperature change in Garamba Park, there is a drop in temperature from May to October.

In Garamba National Park, the more the temperature increases, the more precipitation decreases and vice versa as shown in Figure 5 which shows a positive linear regression between temperature and precipitation with $\mathrm{R}^{2}=0.767$. The correlation between coefficients of Kendal and Pearson respectively -0.763 and -0.876 . This correlation is negative.

\section{Sub Discussion}

The Democratic Republic of Congo is famous of the country is that of having a hot and humid climate over the greatest extent of its territory and abundant

Table 1. Correlation between monthly temperature and monthly precipitation at Garamba.

\begin{tabular}{ccc}
\hline Month & Monthly temperature $\left({ }^{\circ} \mathrm{C}\right)$ & Monthly Precipitation $(\mathrm{mm})$ \\
\hline Jan. & 35 & 10 \\
Feb. & 36 & 23 \\
Mar. & 35 & 63 \\
Apr. & 33 & 86 \\
May & 30 & 85 \\
Jun. & 28 & 103 \\
Jul. & 27 & 121 \\
Aug. & 27 & 132 \\
Sep. & 28 & 90 \\
Oct. & 28 & 122 \\
Nov. & 31 & 74 \\
Dec. & 33 & 19 \\
\hline
\end{tabular}




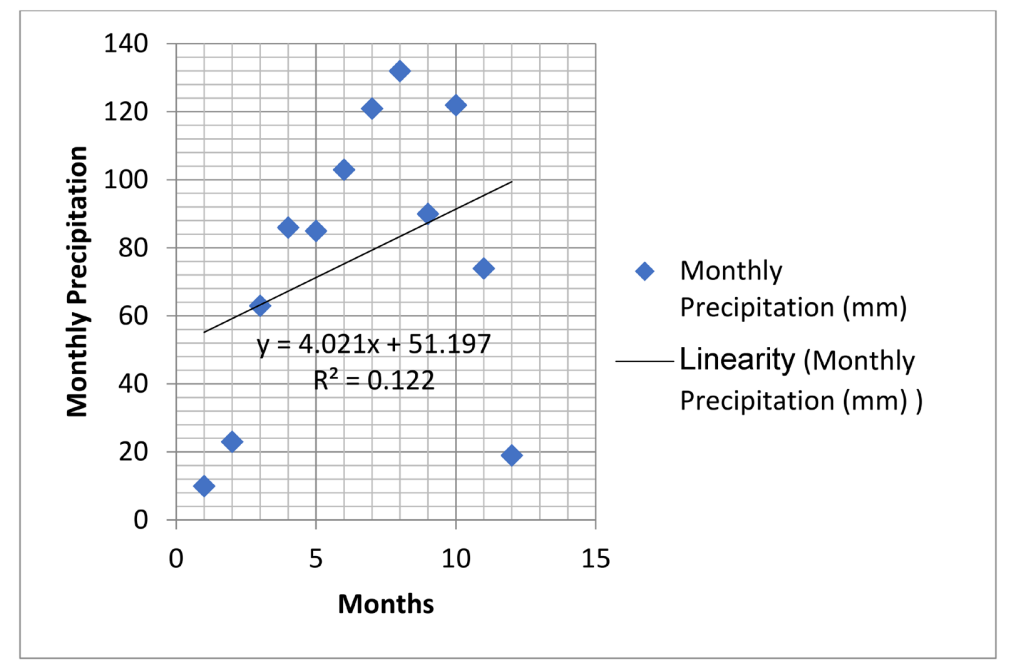

Figure 3. Garamba Monthly precipitation.

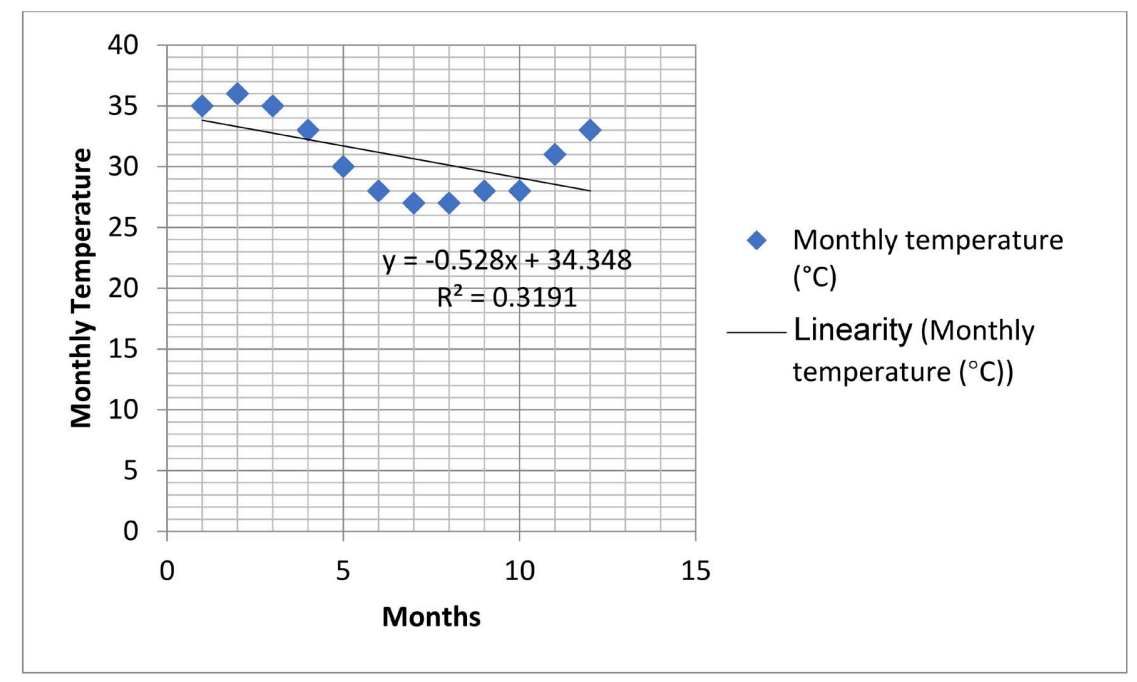

Figure 4. Garamba Monthly Temperature.

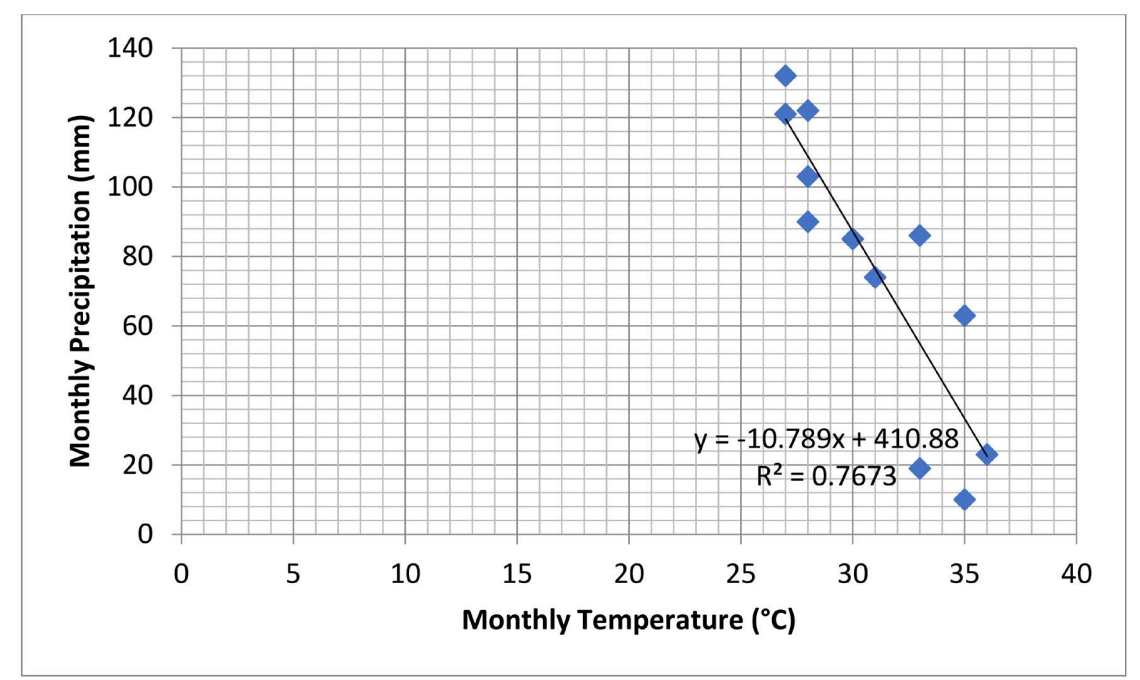

Figure 5. Garamba regression monthly precipitation. 
rainfall, which is found in the equatorial and humid tropical zone. Indeed, the country extends unevenly, straddling the Equator roughly up to $5^{\circ}$ north latitude and $13^{\circ}$ south latitude.

At the equator, the thermometer only rarely drops below $20^{\circ} \mathrm{C}$. On the periphery, on the contrary, the nights are colder. In the northeast, east and southeast, regions of plateaus and mountains, the altitude changes the climatic conditions considerably. The temperature is on average $25^{\circ} \mathrm{C}$ around the basin, $26^{\circ} \mathrm{C}$ on the coast, $18^{\circ} \mathrm{C}$ to $20^{\circ} \mathrm{C}$ at an altitude of 1500 meters, $16^{\circ} \mathrm{C}$ to $17^{\circ} \mathrm{C}$ at 2000 , $11^{\circ} \mathrm{C}$ at 3000 meters and $6^{\circ} \mathrm{C}$ at 4000 meters.

The influences of the seasons on the growth of vegetation are very important for a better conservation of nature. Observing the images got from NASA, Meteosatetc of the environment shows forests in a patchy fashion. The real-time satellite image combines visible light during the day and infrared radiation at night. At night, the image is not dark because infrared radiation can detect temperature differences. Unfortunately, low clouds and fog are difficult to distinguish from ground temperatures and therefore can be almost invisible at night.

Precipitation is estimated from radars and satellites. The calculations of precipitation for the night by the satellite are less precise than for the day.

Predictability is the estimated certainty of our forecast. It considers the uncertainties in relation to pressure, precipitation, temperature, wind, and large-scale phenomena and climatic inconsistencies. We expect constant high or very high predictability in regions of high pressure and places of low climatic variance (such as deserts). Predictability is lower for low pressure phenomena, such as heavy precipitation events and thunderstorms. Our goal is to show that some weather events are not so easy to predict and that some forecasts may be wrong or may change completely within 12 hours.

Table 1 shows that the monthly regression between temperature and precipitation is 0.767 while table (Appendix A2; Appendix A3) also shows that the correlation coefficient between precipitation and temperature is negative -0.876 for the Pearson correlation and -0.763 for the Kendall correlation [ -0.876 and -0.763 is correlation significant at the 0.01 level (2_tailed)].

During the last ice ages, the average temperature of the Earth's atmosphere at ground level was $4^{\circ} \mathrm{C}$ to $5^{\circ} \mathrm{C}$ lower than the current average, while some tropical areas had average temperatures about the same as they are now.

Maximum temperatures are expected to rise more than minimum and more than average. In addition, annual average precipitation will decrease over most of the Mediterranean region. This significant drop in rainfall should be between $-4 \%$ and $-27 \%$.

The Democratic Republic of Congo included, in principle, two seasons dry and rain. The same way throughout the territory and is neither equal in terms of duration. In the northern part of the country, the rainy seasons last from April to the end of June and from September to the end of October. The dry seasons last from early November too late March (large dry season) and from early July 
to late August (short dry season). South of the equator, the rhythm of the seasons is exactly reversed. In the mountainous regions of the east, the two dry seasons last only one month, in January and July. In southern and southeastern Katanga, the rainy season begins in mid-October and continues until mid-May. In North Katanga and South Kasai, the rains start in early October and end at the end of April, but there is a short dry season in January. The water deficit results from increased decrease in precipitation and evaporation causing the vegetation to dry out leading to soil degradation. To fight against this degradation of the soil, it is necessary to carry out several studies on the variation of the vegetation which is effective to detect the factors limiting the vegetation growth in this park and its province of Haut Uele.

\subsection{Correlation between NDVI, EVI, LST and Precipitation at Garamba}

To improve our work, we have used remote sensing techniques as vegetation indices have become an increasingly important instrument and used to assess landscape units. some indices such as NDVI, EVI are very important tools in the study of the behavior of vegetation under the most different climatic conditions, notably in the Democratic Republic of the Congo in general and the Garamba National Park in particular. This study allowed us to assess the influence of precipitation on the behavior vegetation preserved in Garamba national park through vegetation indices using satellite images.

\subsubsection{NDVI at Garamba}

Figure 6(a) and Figure 6(b) show the importance and evolution of Normalized difference vegetation index inGaramba National Park during the three decades.

Given the variability of the time steps at which the different types of changes can be observed reflecting the vegetation dynamics of the savannas, it is advisable to use a series of satellite images with high temporal repetitiveness as long as possible. In addition, the great spatial heterogeneity of the structure of the savannas necessitates the use, among the images with high temporal repetitiveness, those exhibiting the finest spatial resolution in the spectral bands required for the measurement of NDVI.

In a remote sensing approach, all these transformations are not observed at the same scale. At the scale of the spatial resolution of images with high temporal repeatability, several studies have shown the ability of NDVI to serve as indirect data to measure biophysical variables characterizing the state of the plant cover (rate of plant cover, green biomass produced). The analysis of intra- and inter-annual variations of NDVI makes it possible to measure the changes relating to a modification of these physical variables.

\subsubsection{EVI at Garamba}

Figure 7(a) and Figure 7(b) show the importance and evolution of enhanced vegetation index in Garamba National Park during the three decades. 

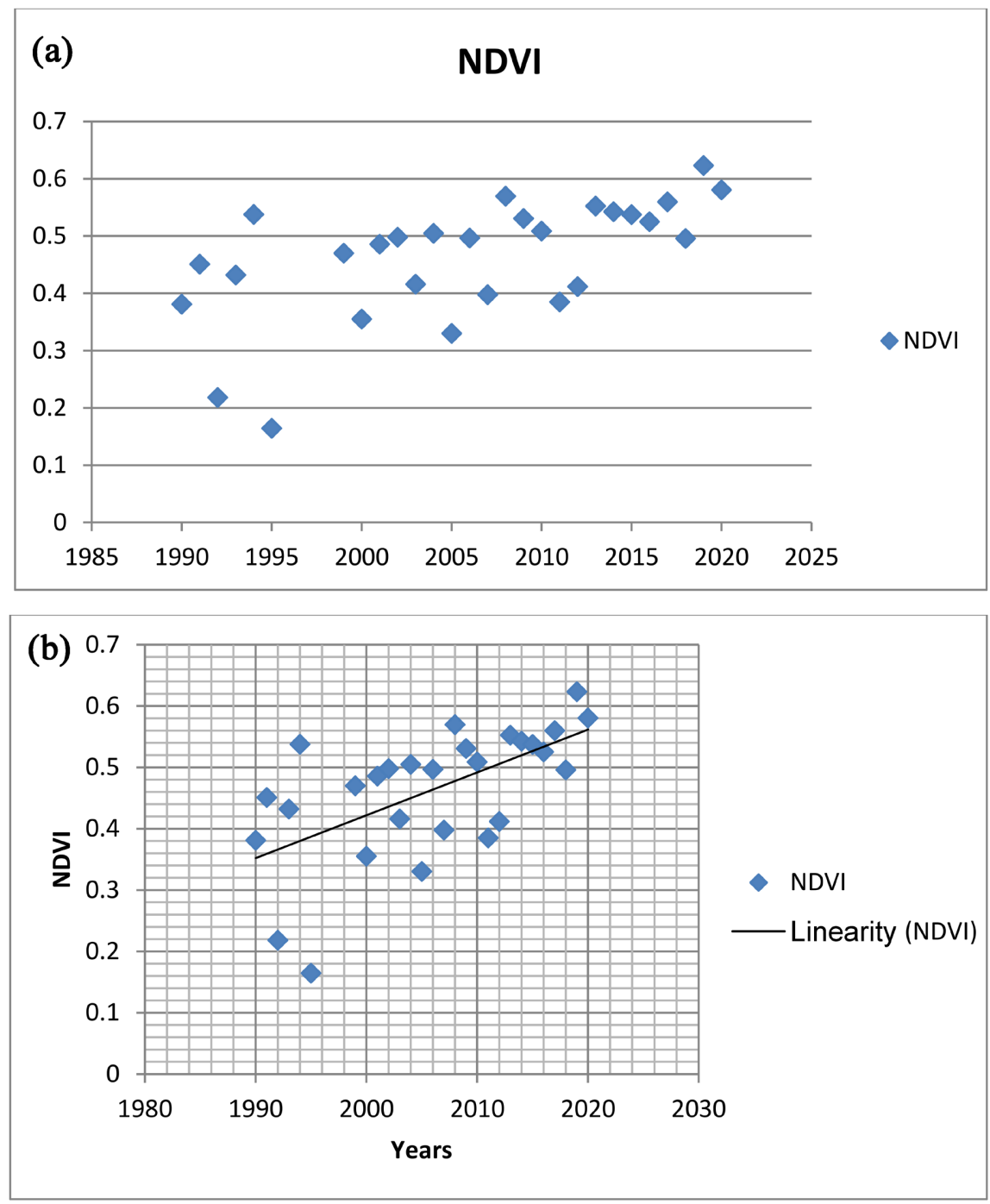

Figure 6. (a) Garamba NDVI; (b) Garamba Regression NDVI.

During our writing, EVI was optimized for us in order to improve the description of the variability in the case of high biomasses, and is therefore more revealing of the variations in the structure of the vegetation cover. Based on the multispectral nature of satellite data, they make it possible to describe the state of a phenomenon. A vegetation index, for example, can reflect the stage of plant growth at a given time.

Based on the multispectral nature of satellite data, they make it possible to describe the state of a phenomenon. A vegetation index, for example, can reflect the stage of plant growth at a given time.

All indices, whether vegetation indices, soil indices, water column indices, etc., are based on an empirical approach based on experimental data. Vegetation indices are widely used, on the one hand, to identify and monitor vegetation dynamics, but also to estimate certain biophysical parameters characteristic of plant cover, such as biomass, leaf area index, photosynthetic radiation fraction, active, etc. 

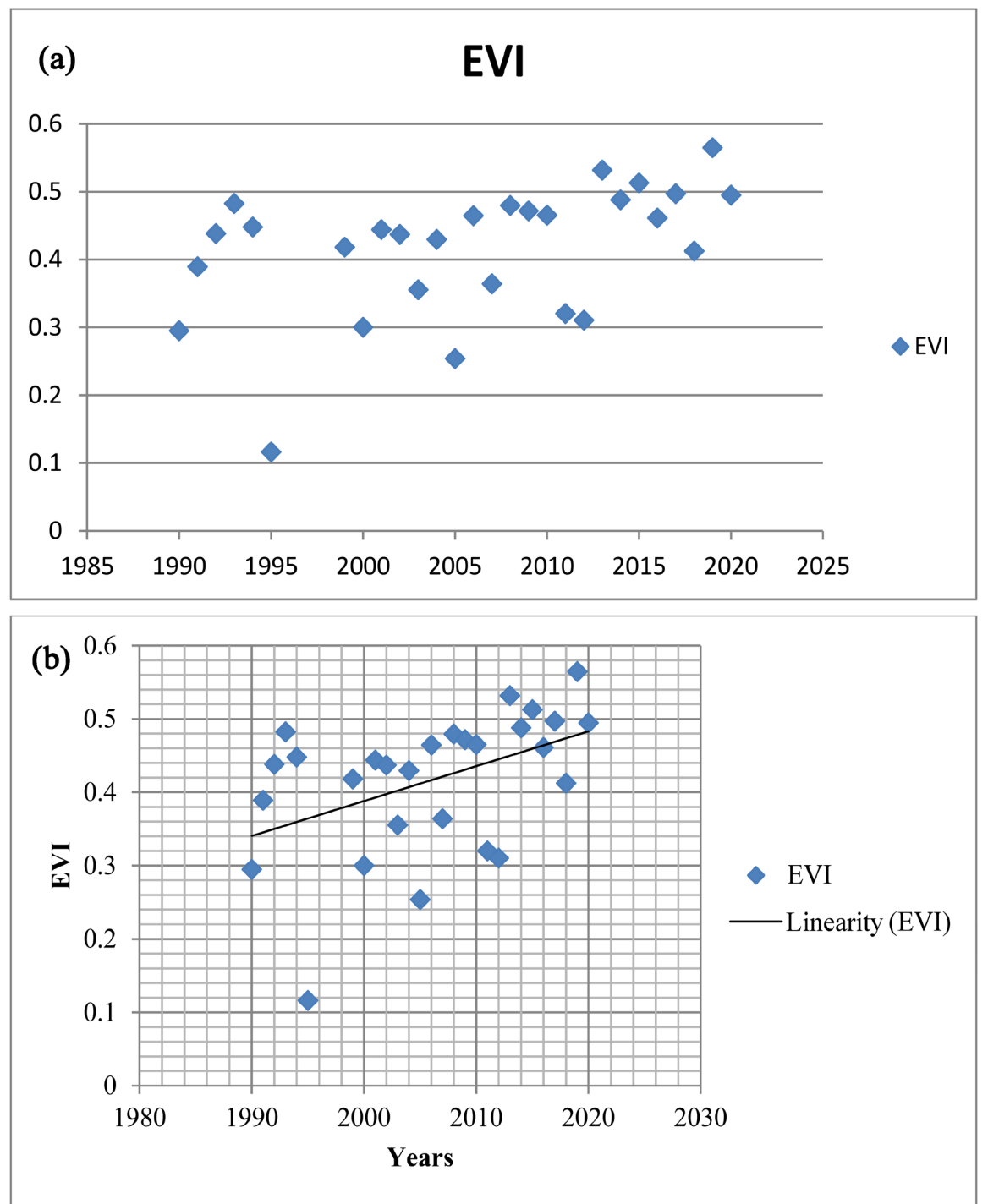

Figure 7. (a) Garamba EVI; (b) Garamba Regression EVI.

In remote sensing, indices are part of processing methods called multispectral transformations. They consist in converting the luminance's measured at the level of the satellite sensor into quantities having a significance in the field of the environment.

\subsubsection{LST at Garamba}

Figure 8(a) and Figure 8(b) show that there has been a progressive evolution of the temperature from the surface of the ground to the national park of the Garamba during these 3 decades.

\subsubsection{Precipitation at Garamba}

When rains fall on land covered by forest, the first effect of the forest is interception. Depending on the nature of the rain and the density of the vegetation, a variable quantity of water is retained by the leafy canopy of the forest and evaporated into the atmosphere without reaching the ground. Precipitation plays a 

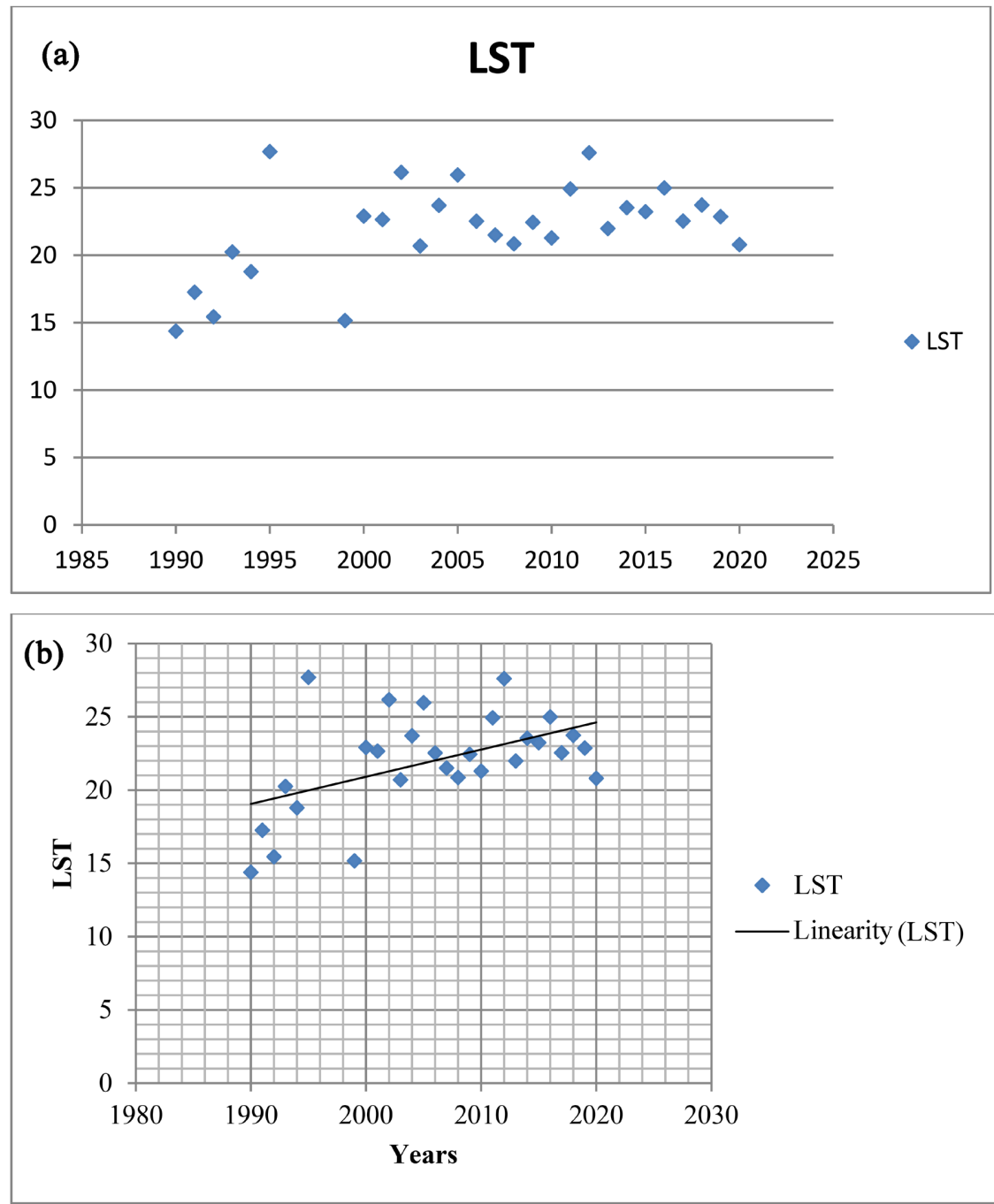

Figure 8. (a) Garamba LST; (b) Garamba Regression LST.

very important role in vegetation, Figure 9(a) and Figure 9(b) show us its evolution as a climatic factor within the Garamba national park.

\subsubsection{Correlation between NDVI and Precipitation at Garamba}

At Garamba, we found that the correlation between NDVI and precipitation in is significant because $\mathrm{p}<0.05$. The linear regression is positive $\left(\mathrm{R}^{2}=0.082\right)$.

The Kendall coefficient between NDVI and precipitation is 0.416 and the Pearson coefficient is also 0.496. These two correlation coefficients made it possible to achieve the same results by different means (Figure 10). The value of these two coefficients shows that the onset of precipitation generally seems to act as a stimulant for vegetation in regions where the amplitude of the annual temperature cycle is small. In areas where the onset of the rainy season is sudden, vegetation tends to lag behind rainfall.

\subsubsection{Correlation between LST and Precipitation at Garamba}

In Garamba we saw that the correlation between LST and precipitation in is not 

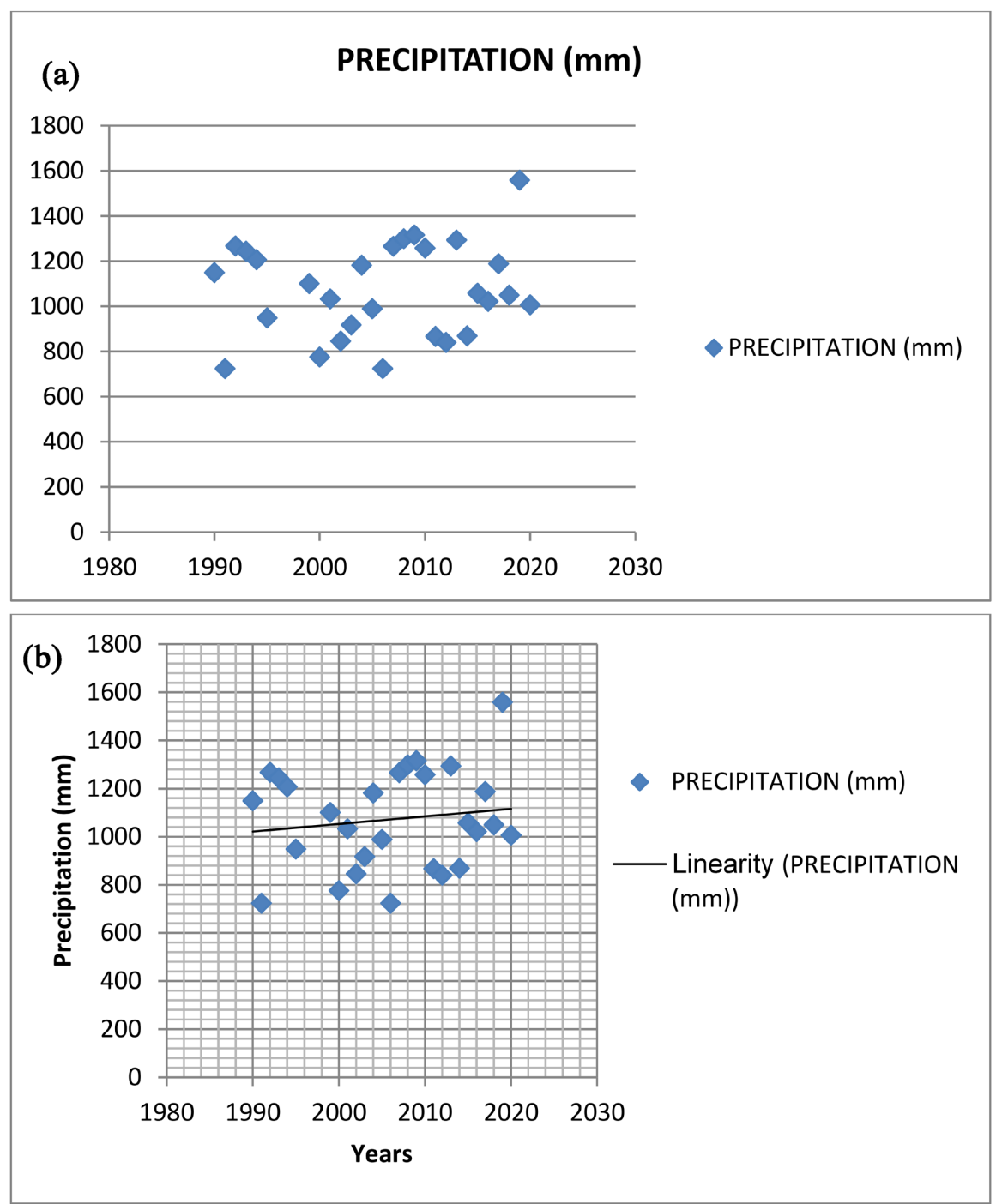

Figure 9. (a) Garamba precipitation; (b) Garamba regression precipitation.

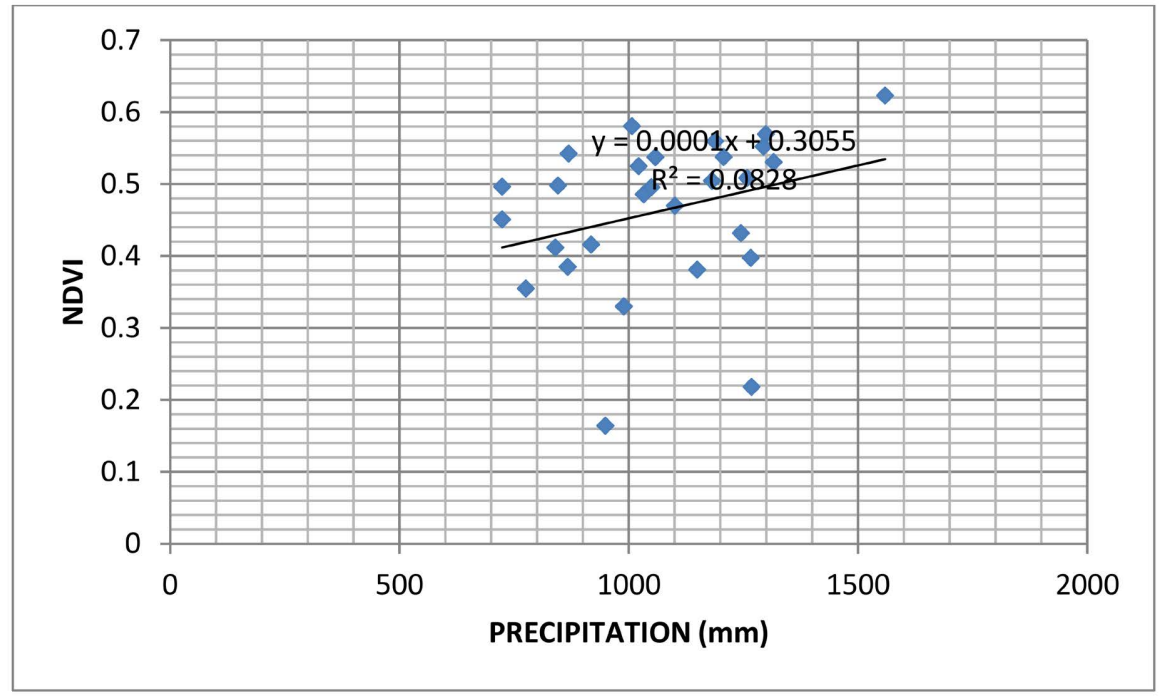

Figure 10. Correlation between NDVI and precipitation at Garamba. 
significant because $\mathrm{p}$ is not greater than 0.05 (Figure 11). Linear regression is negative $\left(\mathrm{R}^{2}=0.082\right)$.

The Kendal's coefficient between LST and precipitation is -0.301 and the Pearson coefficient is also -0.293 . These two correlation coefficients made it possible to achieve the same results by different means.

\subsubsection{Correlation between EVI and Precipitation at Garamba}

Figure 12 shows that the correlation between EVI and precipitation is significant because $\mathrm{p}<0.05$. The Kendal's coefficient between EVI and precipitation is 0.291 and the Pearson coefficient is also at 0.395. EVI is an optimized index designed to improve vegetation signal with improved sensitivity in high biomass areas and improved vegetation monitoring through decoupling of the canopy's background signal and reduced influence of the atmosphere.

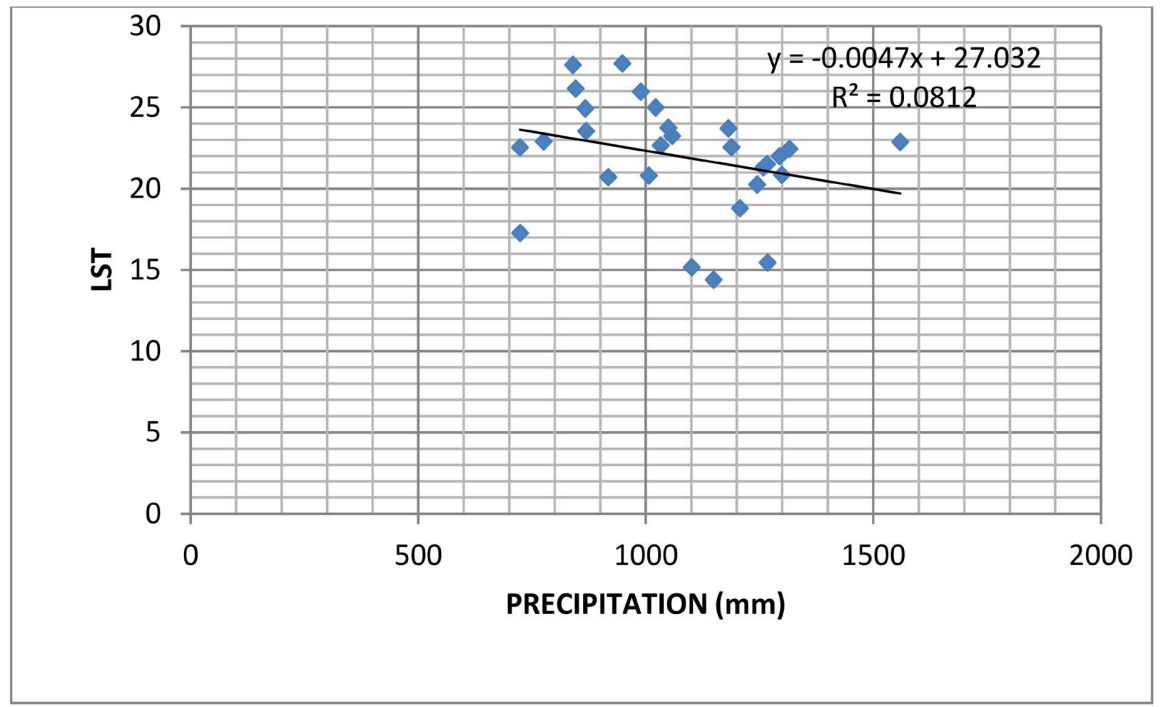

Figure 11. Correlation between NDVI and Precipitation at Garamba.

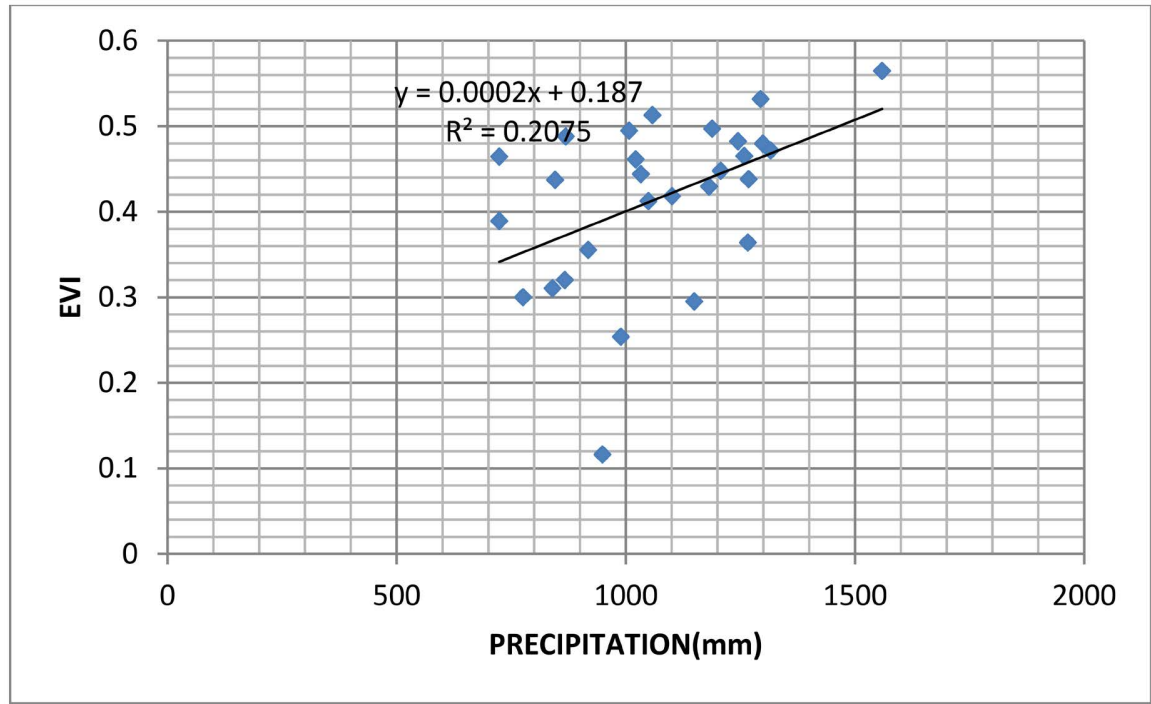

Figure 12. Correlation between NDVI and Precipitation at Garamba. 


\section{Discussion}

The different correlations between climatic factors and vegetation indices at the national level of Garamba during these three decades have an exceptional impact on the development of this park dominated by savannah [23] [24]. It can be seen that in this part of the country the whole correlation between NDVI and precipitation or EVI and precipitation is significant and the correlation between land surface temperature and precipitation is not significant. This observation means that under tropical climatic conditions, NDVI relates to the availability of water under certain conditions and not under other conditions [25] [26].

We see an incredible variation in the vegetation index during these three decades in the province of Haut Uele at the national level and Garamba national park at the local level. The correlations of the Kendal coefficient between NDVI and precipitation is 0.416 (significant), EVI and precipitation 0.291 (significant) (p-value $<0.00001$ ), LST and precipitation -0.301 (no significant) while the Pearson correlation coefficient between NDVI and precipitation is 0.496 , EVI and precipitation 0.395; LST and precipitation -0.293 . Vegetation dieback can exacerbate land degradation through feedback between the soil surface and the atmosphere. This occurs when a decrease in vegetation reduces evaporation and increases the radiation returned to the atmosphere, reducing cloud formation. Many factors, natural or man-made, determine the Earth's climate. The climate depends on the redistribution of the energy of the Sun, according to the atmospheric and oceanic currents. Climates largely depend on latitude, longitude and altitude.

Certain combinations such as changes in vegetation index and climate variability can lead to rich data capable of suggesting how to deal with climate change through plant ecology. Vegetation dynamics and climate variability are based on principles study of correlation and regression by analyzing of climate related to vegetation and vice versa [27].

\section{Conclusions}

Ecology designates the production of plant organic matter (biomass), resulting from photosynthesis, by autotrophic organisms, known as primary producers. It reflects the rate at which an amount of organic matter is formed per unit of time, from mineral matter and an input of energy. It is expressed as the mass of carbon assimilated per unit of time.

Modeling the potential production of the different areas of the planet makes it possible to estimate what the plant production would be without human intervention. This considers current climatic data and the potential resources of a soil and an under graded atmosphere. Temperature is one of the main factors governing plant productivity. Along with water availability, temperature is one of the major factors limiting the productivity of terrestrial ecosystems. The temperature of the air and of the plants is subject to strong seasonal and daily variations which are parallel to the amount of solar energy reaching the surface of the 
ground: the rapid changes in the temperature of the leaves, as measured during one day, usually follow the variations in sunshine [28]. Plants respond to changes in temperature by immediately adjusting their activity to new conditions. When the changes in the thermal climate are persistent, the adjustments involved involve more or less rapid and lasting changes in the metabolism. Photosynthesis involves diffusion processes, complex biochemical reactions and the capture of light energy with its transformation into usable energy: [29] [30]. Temperature affects photosynthesis in the short and long term. Plants can, to varying degrees, acclimatize to long-lasting temperature changes: in all cases the temperature at which the maximum photosynthetic activity is observed follows the temperature of growth. Climate variability as a phenomenon has long been studied and characterized. The most important question, both for Africa and in other regions of the world, is the search for explanatory factors. Most of the climate studies carried out were limited to the analysis of annual or monthly rainfall data by [31].

There is a probable link between climatic factors and green plants according to [32]. Several studies show gaps concerning suitable analyses capable of confirming the existing relation between vegetation trends and climatic impacts.

\section{Conflicts of Interest}

The authors declare no conflicts of interest regarding the publication of this paper.

\section{References}

[1] Sakata, G. (2007) Le code forestier et le code minier de la RDC: Rôle des acteurs et impacts socio-économiques et environnementaux. Essai comparatif, Rapport d'étude pour le Musée royal d'Afrique centrale, Tervuren, Bruxelles, mars 2007, 2.

[2] Debroux, L., Hart, T., Kaimowitz, D., Karsenty, A. and Topa, G. (Eds.) (2007) Forests in Post-Conflict in Democratic Republic of Congo: Analysis of a Priority Agenda. CIFOR/Banque mondiale, Bogor, Indonesie.

[3] SPIAF (Service Permanent d'Inventaire et d'Aménagement Forestiers) (1994) Guide Operationnel-Normes de Stratification Forestière.

[4] MECNT Ministere de l'environnement, conservation de la nature, eaux et forets (2004) Programme d'action national de lutte contre la desertification, juin 2004, 23 p.

[5] Organisation des Nations Unies pour l'Alimentation et l'Agriculture (FAO) (2011) Situation des forets du monde. Organisation des Nations Unies pour l'Alimentation et l'Agriculture (FAO), Rome.

[6] Blaser, J., Sarre, A., Poore, D. and Johnson, S. (2011) Status of Tropical Forests Management 2011. ITTO Technical Series No 38, International Tropical Timber Organization (ITTO), Yokohama.

[7] Fandjinou, K., Zhang, K., Folega F., Mukete, B., Yang, X., Wala, K., Akpagana, K. and Bohnett, E. (2020) Assessment of the Protected Areas Strategy in Togo under Sustainable Management: The Case Study of Oti-Keran, Togodo, and Abdoulaye Faunal Reserve. Open Journal of Ecology, 10, 141-159. 
https://doi.org/10.4236/oje.2020.104010

[8] Ernst, C., Mayaux, P., Verhegghen, A., Bodart, C., Musamapa, C. and Defourny, P. (2013) National Forest Cover Change in Congo Basin: Deforestation, Reforestation, Degradation and Regeneration for the Years 1990, 2000 and 2005. Global Change Biology, 19, 1173-1187. https://doi.org/10.1111/gcb.12092

[9] (2000) MECNT Ministère de l'environnement de la RDC, Rapport sur la stratégie de développement rural, programme de relance du secteur forestier. Note de cadrage, mai 2000.

[10] Chuai, X.W., Huang, X.J., Wang, W.J. and Bao, G. (2013) NDVI, Temperature and Precipitation Changes and Their Relationships with Different Vegetation Types during 1998-2007 in Inner Mongolia, China. International Journal of Climatology, 33, 1696-1706. https://doi.org/10.1002/joc.3543

[11] Girard, M.-C. and Girard, C. (2010) Remote Data Managements. https://dunod.googleearth.com/

[12] FAO (Organisation des Nations Unies pour l'Alimentation et l'Agriculture) (2007) Etat des forêts du monde 2007. Organisation des Nations Unies pour l'Alimentation et l'Agriculture, Rome, 109.

[13] De Wasseige, C., Devers, D., de Marken, P., Eba'aAtyi, R., Nasi, R. and Mayaux, P. (Eds.) (2009) Les forets du bassin du Congo: Etat des forets 2008. Office de publication de l'Union europeenne, Luxembourg.

[14] Central African Forests Commission (COMIFAC) (2011) Les forêts du bassin du Congo. Etat des forêts 2010.

[15] Mertens, B. and Belanger, L. (2010) Atlas forestier interactif de la Republique Democratique du Congo: Version 1.0-Donnees 2009. World Resources Institute, Washington DC.

[16] Robert, M. (1942) Le Congo physique. Stoops, Bruxelles, 165.

[17] De Heinzei, InJ. (1933) Sols, paléosols et désertifications anciennes dans le secteur nord-oriental du Congo (Publ. Institut national. Étude agronomique). Congo Belge, Bruxelles, 79.

[18] Hansen, P.M. and Schjoerring, J.K. (2003) Reflectance Measurement of Canopy Biomass and Nitrogen Status in Wheat Crops Using Normalized Difference Vegetation Indices and Partial Least Squares Regression. Remote Sensing of Environment, 86, 542-553. https://doi.org/10.1016/S0034-4257(03)00131-7

[19] Meyer, W.B. and Turner, I.B.L. (1994) Changes in Land Use and Land Cover: A Global Perspective. Cambridge University Press, Cambridge.

[20] Kendall, M. (1938) A New Measure of Rank Correlation. Biometrika, 30, 81-89. https://doi.org/10.1093/biomet/30.1-2.81

[21] Helsel, D.R. and Hirsch, R.M. (2002) Statistical Methods in Water Resources. Studies in Environmental Science 49. Elsevier, New York.

http://water.usgs.gov/pubs/twri/twri4a3/ https://doi.org/10.3133/twri04A3

[22] Yue, S. and Wang, C.Y. (2002) The Applicability of Pre-Whitening to Eliminate the Influence of Serial Correlation on the Mann-Kendall Test. Water Resources Research, 38, 4-1-4-7. https://doi.org/10.1029/2001WR000861

[23] Peters, A.J., Walter-Shea, E.A., Li, J., Vina, A., Hayes, M. and Svoboda, M.D. (2002) Drought Monitoring with NDVI-Based Standardized Vegetation Index. Photogrammetric Engineering and Remote Sensing, 68, 71-75.

[24] Lin, Y., Xin, X., Zhang, H. and Wang, X. (2015) The Implications of Serial Correla- 
tion and Time-Lag Effects for the Impact Study of Climate Change on Vegetation Dynamics-A Case Study with Hulunber Meadow Steppe. Inner Mongolia. International Journal of Remote Sensing, 36, 5031-5044.

https://doi.org/10.1080/01431161.2015.1093196

[25] Omondi, P.A., Awange, J.L., Forootan, E., Ogallo, L.A., Barakiza, R., Girmaw, G.B., et al. (2014) Changes in Temperature and Precipitation Extremes over the Greater Horn of Africa Region from 1961 to 2010. International Journal of Climatology, 34, 1262-1277. https://doi.org/10.1002/joc.3763

[26] Lotsch, A., Friedl, M.A., Anderson, B.T. and Tucker, C.J. (2003) Coupled Vegetation-Precipitation Variability Observed from Satellite and Climate Records. Geophysical Research Letters, 30, Article No. 1774.

https://doi.org/10.1029/2003GL017506

[27] Boukeng Djiongo, J., Desrochers, A., Avana, M., Khasa, D., Zapfack, L. and Fotsing, E. (2020) Analyse de la dynamique spatio-temporelle de l'utilisation des terres dans le parc national de Bouba Ndjidda et sa zone adjacente (Nord Cameroun). Open Journal of Forestry, 10, 39-57. https://doi.org/10.4236/ojf.2020.101004

[28] Breckel, S.-W. (1999) Walter's Vegetation of the Earth. The Ecological Systems of the Geo-Biosphere. Springer, Berlin.

[29] Gabriel, C. (2007) Effet de la température sur la photosynthèse http://hebergement.u-psud.fr/ese/IMG/pdf/Effet de la temperature sur la photos ynthese-3.pdf

[30] Cyrille, N. and Sylvain, A. (2017) Dynamique des paysages végétaux du parc national de la vallée du Mbere et de sa périphérie sud. Open Journal of Ecology, 7, 392-405. https://doi.org/10.4236/oje.2017.76028

[31] Kouassi, A.M., Kouamé, K.F., Koffi, Y.B., Dje, K.B., Paturel, J.E. and Oulare, S, (2010) Analysis of Climate Variability and of Its Influences on Seasonal Rainfall Regimes in West Africa: Case of the N'zi (Bandama) Watershed in Ivory Coast.

[32] Leith, C.E. (1975) Numerical Weather Prediction. Reviews of Geophysics, 13, 681-684. https://doi.org/10.1029/RG013i003p00681 
APPENDIX A1. Correlation between NDVI, PRECIPITATION, EVI and LST/GARAMBA

\begin{tabular}{|c|c|c|c|c|}
\hline \multicolumn{5}{|c|}{ Correlation between NDVI, PRECIPITATION, EVI and LST/GARAMBA } \\
\hline YEAR & NDVI & PRECIPITATION (mm) & EVI & LST \\
\hline 1990 & 0.3812 & 1149.184 & 0.2951 & 14.3872 \\
\hline 1991 & 0.4510 & 723.8128 & 0.3893 & 17.2671 \\
\hline 1992 & 0.2183 & 1267.64 & 0.4382 & 15.4527 \\
\hline 1993 & 0.4321 & 1244.511 & 0.4825 & 20.2561 \\
\hline 1994 & 0.5378 & 1206.991 & 0.448 & 18.7894 \\
\hline 1995 & 0.1644 & 948.7459 & 0.1163 & 27.6999 \\
\hline 1999 & 0.4701 & 1100.904 & 0.4183 & 15.1699 \\
\hline 2000 & 0.3551 & 775.678 & 0.3002 & 22.9095 \\
\hline 2001 & 0.4859 & 1032.866 & 0.444 & 22.654 \\
\hline 2002 & 0.4981 & 845.761 & 0.4372 & 26.1623 \\
\hline 2003 & 0.4161 & 917.734 & 0.3555 & 20.7064 \\
\hline 2004 & 0.5049 & 1181.692 & 0.4297 & 23.712 \\
\hline 2005 & 0.3302 & 988.991 & 0.2539 & 25.9644 \\
\hline 2006 & 0.4967 & 723.65 & 0.4646 & 22.5386 \\
\hline 2007 & 0.3978 & 1266.317 & 0.3641 & 21.5093 \\
\hline 2008 & 0.5696 & 1299.119 & 0.4796 & 20.8573 \\
\hline 2009 & 0.5307 & 1315.779 & 0.4717 & 22.4468 \\
\hline 2010 & 0.5088 & 1258.283 & 0.4653 & 21.2988 \\
\hline 2011 & 0.3852 & 866.965 & 0.3203 & 24.9311 \\
\hline 2012 & 0.4119 & 839.949 & 0.3105 & 27.6051 \\
\hline 2013 & 0.5524 & 1293.898 & 0.5318 & 21.9881 \\
\hline 2014 & 0.5426 & 868.932 & 0.4881 & 23.5373 \\
\hline 2015 & 0.5375 & 1057.88 & 0.513 & 23.2406 \\
\hline 2016 & 0.5253 & 1021.519 & 0.4613 & 24.9969 \\
\hline 2017 & 0.5598 & 1188.4 & 0.4971 & 22.5496 \\
\hline 2018 & 0.4958 & 1049.5 & 0.4125 & 23.7388 \\
\hline 2019 & 0.6233 & 1559.001 & 0.5648 & 22.8706 \\
\hline 2020 & 0.5806 & 1006.8 & 0.4949 & 20.8012 \\
\hline
\end{tabular}




\section{Appendix A2. Monthly Non Parametric Correlations}

\begin{tabular}{|c|c|c|c|c|}
\hline \multicolumn{5}{|c|}{ Garamba Monthly Non Parametric Correlations } \\
\hline & & & $\begin{array}{c}\text { Monthly } \\
\text { Precipitation } \\
\text { (mm) }\end{array}$ & $\begin{array}{c}\text { Monthly } \\
\text { Temperature }\left({ }^{\circ} \mathrm{C}\right)\end{array}$ \\
\hline \multirow{6}{*}{$\begin{array}{l}\text { Kendall's } \\
\text { tau_b }\end{array}$} & \multirow{3}{*}{$\begin{array}{c}\text { Monthly } \\
\text { Precipitation } \\
(\mathrm{mm})\end{array}$} & Correlation coefficient & 1.000 & -0.763 \\
\hline & & Sig (2_tailed) & & 0.001 \\
\hline & & $\mathrm{N}$ & 12 & 12 \\
\hline & \multirow{3}{*}{$\begin{array}{c}\text { Monthly } \\
\text { Temperature }\left({ }^{\circ} \mathrm{C}\right)\end{array}$} & correlation coefficient & -0.763 & 1.000 \\
\hline & & Sig (2_tailed) & 0.001 & \\
\hline & & $\mathrm{N}$ & 12 & 12 \\
\hline
\end{tabular}

\section{Appendix A3. Garamba Monthly Correlation Analysis}

\begin{tabular}{|c|c|c|c|}
\hline \multicolumn{4}{|c|}{ Garamba Monthly Correlation Analysis } \\
\hline & & $\begin{array}{l}\text { Monthly Precipitation } \\
\text { (mm) }\end{array}$ & $\begin{array}{c}\text { Monthly Temperature } \\
\left({ }^{\circ} \mathrm{C}\right)\end{array}$ \\
\hline \multirow{3}{*}{$\begin{array}{l}\text { Monthly Precipitation } \\
\text { (mm) }\end{array}$} & Pearsan's correlation & 1 & -0.876 \\
\hline & Sig (2_tailed) & & 0.000 \\
\hline & $\mathrm{N}$ & 12 & 12 \\
\hline \multirow{3}{*}{ Monthly Temperature $\left({ }^{\circ} \mathrm{C}\right)$} & Pearsan's correlation & -0.876 & 1 \\
\hline & Sig (2_tailed) & 0.000 & \\
\hline & $\mathrm{N}$ & 12 & 12 \\
\hline
\end{tabular}

\section{Appendix A4. Garamba Non ParametricCorrelations}

\begin{tabular}{|c|c|c|c|c|c|c|}
\hline \multicolumn{7}{|c|}{ Garamba Non Parametric Correlations } \\
\hline & & & $\begin{array}{l}\text { Precipitation } \\
(\mathrm{mm})\end{array}$ & LST & EVI & NDVI value \\
\hline \multirow{12}{*}{ Kendall's tau_b } & & correlation coefficient & 1.000 & -0.301 & 0.291 & 0.416 \\
\hline & $\begin{array}{l}\text { Precipitation } \\
\quad(\mathrm{mm})\end{array}$ & Sig (2_tailed) & & 0.030 & 0.069 & 0.009 \\
\hline & & $\mathrm{N}$ & 28 & 28 & 28 & 28 \\
\hline & & correlation coefficient & -0.301 & 1.000 & 0.019 & -0.035 \\
\hline & LST & Sig (2_tailed) & 0.030 & & 0.0911 & 0.833 \\
\hline & & $\mathrm{N}$ & 28 & 28 & 28 & 28 \\
\hline & & correlation coefficient & 0.291 & 0.019 & 1.000 & 0.400 \\
\hline & EVI & Sig (2_tailed) & 0.069 & 0.0911 & & 0.038 \\
\hline & & $\mathrm{N}$ & 28 & 28 & 28 & 28 \\
\hline & & correlation coefficient & 0.416 & -0.035 & 0.400 & 1.000 \\
\hline & NDVI value & Sig (2_tailed) & 0.009 & 0.833 & 0.038 & \\
\hline & & $\mathrm{N}$ & 28 & 28 & 28 & 28 \\
\hline
\end{tabular}




\section{Appendix A5. Garamba Correlation Analysis}

\begin{tabular}{|c|c|c|c|c|c|}
\hline \multicolumn{6}{|c|}{ Garamba Correlation Analysis } \\
\hline & & $\begin{array}{l}\text { Precipitation } \\
(\mathrm{mm})\end{array}$ & LST & EVI & NDVI value \\
\hline \multirow{3}{*}{$\begin{array}{l}\text { Precipitation } \\
\quad(\mathrm{mm})\end{array}$} & Pearsan's correlation & 1 & -0.293 & 0.395 & 0.496 \\
\hline & Sig (2_tailed) & & 0.131 & 0.038 & 0.007 \\
\hline & $\mathrm{N}$ & 28 & 28 & 28 & 28 \\
\hline \multirow{3}{*}{ LST } & Pearsan's correlation & -0.293 & 1 & 0.059 & 0.065 \\
\hline & Sig (2_tailed) & 0.131 & & 0.766 & 0.744 \\
\hline & $\mathrm{N}$ & 28 & 28 & 28 & 28 \\
\hline \multirow{3}{*}{ EVI } & Pearsan's correlation & 0.395 & 0.059 & 1 & 0.400 \\
\hline & Sig (2_tailed) & 0.038 & 0.766 & & 0.035 \\
\hline & $\mathrm{N}$ & 28 & 28 & 28 & 28 \\
\hline \multirow{3}{*}{ NDVI Value } & Pearsan's correlation & 0.496 & 0.065 & 0.400 & 1 \\
\hline & Sig (2_tailed) & 0.007 & 0.744 & 0.035 & \\
\hline & $\mathrm{N}$ & 28 & 28 & 28 & 28 \\
\hline
\end{tabular}

